\title{
PENGARUH PENERAPAN NILAI-NILAI ISLAM DAN KOMITMEN TERHADAP ETOS KERJA DAN DAMPAKNYA KEPADA KUALITAS SUMBER DAYA MANUSIA DI LINGKUNGAN PEMERINTAH KABUPATEN TASIKMALAYA
}

\author{
Maman Sulaeman \\ Dosen Politeknik Triguna Tasikmalaya \\ Jl. Letjen Ibrahim Adjie No.7, Indihiang, Tasikmalaya, Jawa Barat 46151 \\ Email korespondensi: mansulaeman1274@gmail.com
}

Naskah diterima: Maret 2016, disetujui: September 2016

\begin{abstract}
The objectives of the research were to know and to analyze the influence of religious value and commitment application to work ethos and their impact to human resources quality in the Government City of Tasikmalaya. The research method used survey method. The data gathering used questionnaires and library study. The population in this research was 8984 Civil Servants in the Government City of Tasikmalaya. The sample of this research used proportional random sampling. By using path analysis, the study found that religious values, commitment, and work ethos have a significant impact to work quality. Simultaneously, religious value, commitment and work ethos have a significant impact to work quality, so the hypothesis was verified.
\end{abstract}

Keywords: moslem value, commitment, work ethos, work quality.

JEL Classifications: Z120, M54.

Abstrak: Tujuan penelitian ini adalah untuk mengetahui pengaruh nilai-nilai religi dan komitmen terhadap etos kerja dan dampaknya kepada kualitas kerja sumber daya manusia di lingkungan Pemerintah Kabupaten Tasikmalaya. Metode penelitian yang digunakan adalah metode survey. Pengumpulan data diperoleh melalui kuesioner dan studi pustaka. Populasi dalam penelitian ini adalah 8984 Pegawai Negeri Sipil di lingkungan Pemerintah Kabupaten Tasikmalaya. Penentuan sampel menggunakan proporsional random sampling dan analisis data yang digunakan adalah analisis jalur. Hasil penelitian menemukan bahwa secara parsial nilainilai religi, komitmen, etos kerja berpengaruh positif terhadap kualitas kerja. Secara simultan nilai-nilai religi, komitmen, etos kerja berpengaruh positif terhadap kualitas kerja sehingga hipotesis teruji kebenarannya.

Kata Kunci: nilai islam, komitmen, etos kerja, kualitas kerja.

Klasifikasi JEL: Z120, M54. 


\section{PENDAHULUAN}

Dalam rangka mewujudkan good corporate governance dan pemerintahan yang memiliki daya saing global diperlukan Sumber Daya Manusia (SDM) yang mumpuni. Pada saat ini sangat dirasakan kompetisi yang ketat di dunia kerja sebagai dampak adanya resesi global, maka organisasi memerlukan SDM yang profesional dan memiliki integritas dalam bekerja. Kompetensi spiritual memiliki peran utama dalam mewujudkan integritas sebagai perilaku kunci untuk membangun kepercayaan dan akhlak yang luhur berdasarkan nilai-nilai agama.

Kemampuan untuk mengelola SDM, berupa pemberdayaan karyawan akan dapat meningkatkan komitmen karyawan terhadap organisasi. Karyawan yang komitmen akan memberikan dampak yang besar terhadap pencapaian kinerja (performance) organisasi. Sumber daya manusia dalam hal ini harus siap, mau dan mampu memberikan sumbangan terhadap usaha pencapaian tujuan organisasional. Nilai-nilai tertentu yang ada dalam organisasi merupakan kekuatan yang potensial untuk mengarahkan karyawan dan organisasi kepada pencapaian tujuannya. Sebagai organisasi yang selalu dihadapkan pada perkembangan kemajuan ilmu pengetahuan dan teknologi, instansi pemerintahan harus memiliki nilai-nilai moral tertentu yang menjadi pedoman bagi para karyawannya untuk mencapai tujuannya. Pada beberapa organisasi, moral atau etika ini kemudian dikembangkan ke arah spiritual atau nilai-nilai Islam (Ancok dan Suroso, 2008).

Kunci kemajuan dan keberhasilan suatu organisasi adalah etos kerja. Etos kerja merupakan komponen primer yang harus dimiliki oleh sumber daya manusia yang berkualitas (Sinamo, J., 2008). Secara umum etos kerja pegawai mesih cenderung rendah. Hal ini dapat dilihat dalam hal ketidaktepatan waktu. Seringkali terjadi keterlambatan memulai suatu acara, keterlambatan jam masuk kerja, keterlambatan jadwal pemberangkatan alat transportasi atau keterlambatanketerlambatan lain yang disebabkan ketidak disiplinan akan waktu.

Kondisi di atas juga terjadi di Kabupaten Tasikmalaya. Pada lingkungan Pemerintahan Kabupaten Tasikmalaya, masih banyak Pegawai Negeri Sipil yang belum memiliki disiplin yang baik. Hal ini terlihat dari pelaksanaan apel pagi di lingkungan Sekretariat Daerah Kabupaten Tasikmalaya. Banyak PNS yang kesiangan mengikuti apel pagi, bahkan tidak ikut sama sekali.

Citra Kabupaten Tasikmalaya sebagai kota santri dan masyarakatnya yang damai, santun, taat beragama serta ramah diharapkan Pegawai Negeri Sipil yang beragama Islam memiliki etos kerja yang baik. Etos kerja sangat erat kaitannya dengan nilai yang dianut oleh seseorang. Bekerja bagi seorang muslim adalah suatu upaya yang sungguh- sungguh, dengan mengerahkan seluruh aset, fikir dan, dzikirnya untuk mengaktualisasikan atau menampakkan arti dirinya sebagai hamba Allah yang harus menundukkan dunia dan menempatkan dirinya sebagai bagian dari masyarakat yang terbaik (Santoso, 2006).

Keberhasilan organisasi dalam pencapaian tujuannya tergantung pada seberapa besar kualitas kerja pegawai dan elemen yang ada di dalamnya. Kualitas kerja yang optimal yang ditunjukan oleh pegawai atau oleh seluruh sub sistem organisasi akan menghasilkan kerja yang berkualitas serta menjadi modal organisasi untuk menanam benih kepercayaan publik. Kualitas kerja sangat tergantung pada nilai-nilai, serta motivasi dan gairah kerja pegawai dalam bertindak.

Kualitas kerja pegawai merupakan tuntutan yang tidak bisa dihindarkan lagi apabila suatu instansi pemerintah menginginkan tercapainya tujuan organisasi. Terlebih para aparat yang secara konstitusional dibentuk untuk memberikan pelayanan kepada masyarakat. Kualitas kerja merupakan wujud perilaku dari 
suatu kegiatan yang telah dilaksanakan dan sesuai dengan harapan yang telah ditentukan sebelumnya. Kualitas kerja merupakan jawaban berhasil atau tidaknya dalam menciptakan dan menumbuhkan perilaku para pegawai untuk bekerja sama dengan pegawai lainnya dan juga sebagai indikator apakah tugas, fungsi dan tanggung jawab serta tujuan-tujuan apakah sudah tercapai secara optimal.

Terciptanya kualitas kerja apabila setiap individu dalam organisasi memiliki komitmen yang tinggi dalam melaksanakan visi dan misi organisasi. Karena itu setiap PNS sebagai Aparatur Pemerintah dituntut memiliki komitmen tersebut agar kinerja organisasi pemerintah yang dalam melaksanakan tanggungjawabnya yaitu melindungi, melayani, dan mengatur rakyat, dapat optimal.

Kualitas kerja yang masih rendah dapat dilihat dari kurangnya mengoptimalkan potensi diri seperti dalam pelaporan yang tidak selesai tepat waktu, hasil kerja yang tidak optimal yang tidak sesuai dengan intruksi pimpinan, belum lengkapnya bukti laporan-laporan administrasi perkantoran sesuai dengan ketentuan yang berlaku, dan antusiasme masih kurang, yaitu kurangnya mengindahkan saran atau masukan dari rekan kerja dan pimpinan dan sering terjadi data yang dihasilkan kurang akurat, beberapa orang yang meminta data dan laporan kurang ditanggapi dan tidak ramah dalam memberikannya.

Berdasarkan uraian di atas maka peneliti tertarik untuk melihat pengaruh penerapan nilai-nilai Islam dan komitmen terhadap etos kerja serta dampaknya terhadap kualitas kerja Pegawai Negeri Sipil di lingkungan Pemerintah Kabupaten Tasikmalaya.

\section{METODE PENELITIAN}

Penelitian ini termasuk dalam kategori penelitian verifikatif. Penelitian verifikatif pada dasarnya ingin menguji kebenaran melalui pengumpulan data di lapangan. Sifat verifikatif pada dasarnya ingin menguji kebenaran dari suatu hipotesis yang dilaksanakan melalui pengumpulan data di lapangan.

\section{Operasionalisasi Variabel}

Berdasarkan judul dari penelitian ini yaitu pengaruh penerapan nilai-nilai religi terhadap etos kerja dan dampaknya kepada kualitas kerja sumber daya manusia di lingkungan pemerintah Kabupaten Tasikmalaya, maka penulis mengungkapkan beberapa penelitian variabel yang dioperasionalkan, yaitu sebagai berikut :

(1) Variabel Independen

Yaitu variabel yang keberadaannya tidak dipengaruhi dan tidak tergantung kepada variabel lain atau variabel yang berdiri sendiri. Variabel independen dalam penelitian ini adalah penerapan nilai-nilai religi (X1), dan komitment (X2).

(2) Variabel Dependen

Yaitu suatu variabel terikat atau tidak bebas atau dengan kata lain variabel yang dipengaruhi oleh variabel independen atau variabel lain. Adapun yang berfungsi sebagai variabel dependen dalam penelitian ini adalah etos kerja $(\mathrm{Y})$ dan kualitas kerja $(Z)$.

\section{Teknik Pengumpulan Data}

Populasi pada penelitian ini adalah seluruh PNS di lingkungan Pemerintahan Kabupaten Tasikmalaya sebanyak 8984 orang. Ukuran sampel dalam penelitian ini menggunakan rumus sebagai berikut:

$$
n=\frac{N}{1+N\left(d^{2}\right)}
$$

Keterangan:

$\mathrm{n}$ = Ukuran sampel

$\mathrm{N}=$ Ukuran populasi

$\mathrm{d}=$ Tingkat kesalahan $10 \%(0,1)$

$$
\begin{gathered}
n=\frac{N}{1+N\left(d^{2}\right)} \\
n=\frac{8984}{1+8984\left(0,1^{2}\right)}
\end{gathered}
$$




$$
\begin{gathered}
n=\frac{8984}{1+89,84} \\
n=90,91 . \text { Dibulatkan } 91 .
\end{gathered}
$$

Berdasarkan hasil perhitungan diatas, maka jumlah sampel minimal pada penelitian ini sebanyak 91 orang. Namun dengan adanya pembulatan sampel pada setiap OPD dan penambahan sampel agar setiap OPD terwakili maka jumlah sampel yang diteliti sebanyak 124 PNS.

Mengacu kepada landasan teori dan kerangka pemikiran dalam gambar yang menghubungkan keterkaitan antara variabel $X$, Y dan Z. Maka analisis yang digunakan dalam penelitian ini adalah path analysis. Dengan analisis ini dapat dilihat besarnya koefisien jalur antara variabel bebas X1 dan X2 dengan variabel terikat $Y$ dan $Z$. Persamaan struktural yang menggambarkan hipotesis adalah:

$\mathrm{Y}=\mathrm{pyx}_{\mathrm{X}} \mathrm{X} 1+\mathrm{p}_{\mathrm{y}} \mathrm{2} 2 \mathrm{X} 2+\mathrm{p}_{\mathrm{y}} \varepsilon 1$

$Z=p_{z x 1} X 1+p_{z x} X 2+z y Y+p_{z} \varepsilon 2$

Berdasarkan data yang sudah tersusun, tahap selanjutnya menentukan jumlah skor untuk masing masing variabel, karena skor merupakan data yang terbentuk ordinal, untuk keperluan perhitungan selanjutnya data tersebut perlu ditransformasikan kedalam bentuk data interval dengan menggunakan metode successive interval. Setelah itu, nilai-nilai skor untuk variabel dan tahap terakhir dilakukan

penghitungan analisis jalur (path analysis). Pengaruh keterkaitan antar variable dapat dilihat sebagaimana gambar dibawah ini :

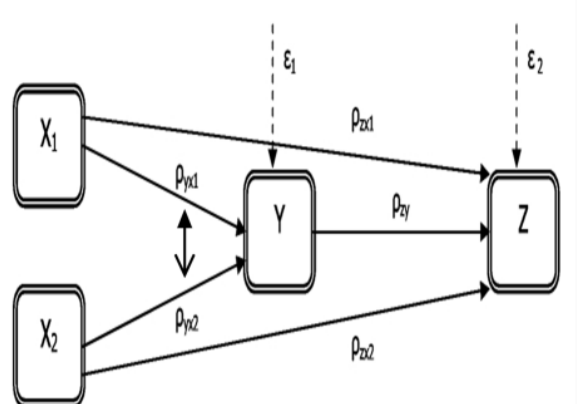

Gambar 1. Hubungan X1, X2, Y dan Z

Dimana:

$$
\begin{array}{ll}
\mathrm{X} 1 & =\text { Nilai Islam } \\
\mathrm{X} 2 & =\text { Komitmen } \\
\mathrm{Y} & =\text { Etos Kerja } \\
\mathrm{Z} & =\text { Kualitas Kerja }
\end{array}
$$

\section{HASIL DAN PEMBAHASAN}

Pengaruh Nilai-Nilai Religi (X1) dan Komitmen (X2) Terhadap Etos Kerja (Y) Sumber Daya Manusia di Pemerintah Kabupaten Tasikmalaya.

Hasil pengolahan data dapat diketahui pengaruh secara parsial dan simultan nilai- nilai religi dan komitmen terhadap etos kerja sumber

\begin{tabular}{|c|c|c|c|c|c|c|}
\hline \multirow[t]{2}{*}{ Model } & \multicolumn{2}{|c|}{$\begin{array}{l}\text { Unstandardized } \\
\text { Coefficients }\end{array}$} & \multirow{2}{*}{$\begin{array}{c}\text { Standardized } \\
\text { Coefficients }\end{array}$} & & \multirow[t]{2}{*}{$\mathrm{t}$} & \multirow[t]{2}{*}{ Sig. } \\
\hline & $\mathrm{B}$ & Std. Error & & & & \\
\hline (Constant) & .417 & 3.068 & & & .136 & .892 \\
\hline Religi & .181 & .019 & & .662 & 9.529 & .000 \\
\hline Komitmen & .197 & .115 & & .119 & 1.716 & .089 \\
\hline
\end{tabular}
daya manusia di lingkungan Pemerintah Kabupaten Tasikmalaya dapat dilihat pada tabel 1.

Tabel 1. Pengaruh Secara Parsial dan Simultan Nilai- Nilai Religi dan Komitmen Terhadap Etos Kerja Sumber Daya Manusia di Lingkungan Pemerintah Kabupaten Tasikmalaya

Dependent Variabel: Etos

Sumber: data diolah 
Pengaruh secara parsial nilai-nilai religi terhadap Etos Kerja

Hasil penghitungan SPSS diperoleh $t$ hitung $=9,529$ sedangkan $\mathrm{t}$ tabel sebesar 1,66 dengan demikian $t$ hitung $>t$ tabel sehingga dapat dikatakan bahwa terdapat pengaruh positif nilai-nilai religi terhadap etos pegawai.

Religiusitas mempunyai pengaruh positif dan signifikan terhadap etos kerja. Dalam organisasi jika setiap karyawan mempunyai religiusitas seperti mengikuti kegiatan beribadah, pergi ke pengajian, menginfakkan sebagian rizki, selalu berdoa, meningkatkan pengetahuan agama, mengasihi sesama, penyabar, tidak pemarah dan jujur maka akan mempengaruhi etos kerja mereka.

\section{Pengaruh secara parsial komitmen terhadap Etos Kerja}

Pengaruh secara parsial komitmen terhadap etos kerja Pegawai Negeri Sipil di lingkungan Pemerintah Kabupaten Tasikmalaya atau $\rho Y X 2$ sebesar 0,119. Untuk pengujian hipotesis secara parsial pengaruh komitmen
(X2) terhadap etos kerja $(\mathrm{Y})$ dengan kriteria penolakan Ho jika $t$ hitung>t tabel. Hasil penghitungan SPSS diperoleh $\mathrm{t}$ hitung $=1,716$ sedangkan $t$ tabel sebesar 1,66 dengan demikian $\mathrm{t}$ hitung $>\mathrm{t}$ tabel sehingga dapat dikatakan bahwa terdapat pengaruh positif komitmen terhadap etos kerja pegawai.

Komitmen adalah kemampuan dan kemauan untuk menyelaraskan perilaku pribadi dengan kebutuhan, prioritas dan tujuan organisasi. Hal ini mencakup cara- cara mengembangkan tujuan atau memenuhi kebutuhan organisasi yang intinya mendahulukan misi organisasi dari pada kepentingan pribadi.

\section{Pengaruh secara simultan nilai-nilai religi dan komitmen terhadap Etos Kerja}

Besarnya pengaruh secara simultan nilainilai religi (X1) dan komitmen (X2) terhadap etos kerja (Y) dapat dilihat dari indikator yang digunakan masing-masing variabel dengan menggunakan path analysis diperoleh hasil 2 yx1x2 yang dapat dilihat pada tabel 2 .

Tabel 2. Pengaruh Secara Simultan Nilai-Nilai Religi dan Komitmen Terhadap Etos Kerja

\begin{tabular}{|c|c|c|c|c|}
\hline Model & $\mathrm{R}$ & $\begin{array}{c}\mathrm{R} \\
\text { Square }\end{array}$ & $\begin{array}{c}\text { Adjusted R } \\
\text { Square }\end{array}$ & $\begin{array}{l}\text { Std. Error of } \\
\text { the Estimate }\end{array}$ \\
\hline 1 & $.719^{a}$ & .517 & .509 & 2.20458 \\
\hline
\end{tabular}

Predictors: (Constant), Komitmen, Religi

Sumber: data diolah

Berdasarkan Tabel 2 terlihat nilai $\rho 2 y x 1 \times 2$ sebesar 0,517 atau $51,7 \%$ artinya jika nilai-nilai religi, dan komitmen secara bersama-sama meningkat akan memberikan dampak positif, maka etos kerja pegawai juga akan meningkat. Hasil perhitungan SPSS diperoleh nilai $\mathrm{F}$ hitung sebesar $64.813>$ F-tabel 2,69 sehingga dapat disimpulkan bahwa terdapat pengaruh positif nilai-nilai religi dan komitmen terhadap etos kerja pegawai.

Secara lengkap pengaruh antara variabel nilai-nilai religi $(X 1)$, dan komitmen $(X 2)$ terhadap etos kerja $(\mathrm{Y})$ dapat dilihat sebagai berikut:

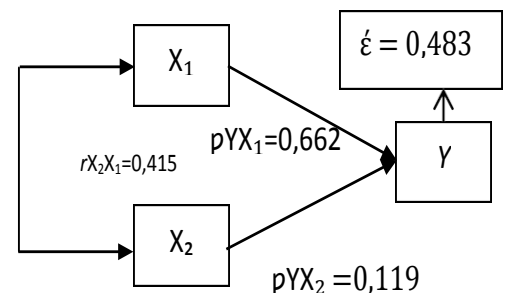

Gambar 2. Nilai Koefisien Jalur Antara Variabel $\mathrm{X} 1, \mathrm{X} 2$ dan $\mathrm{Y}$

Berdasarkan Gambar 2 di atas dapat dilihat pengaruh langsung dan tidak langsung antara 
variabel yaitu:

Pengaruh (X1) terhadap Y:

Pengaruh langsung

$=0.4382$

Pengaruh melalui (X2)

Pengaruh total (X1)

$=\underline{0.0326}+$

$=0,4708$

Pengaruh (X2) terhadap Y:

Pengaruh langsung

$=0.0142$

$=\underline{0.0327}+$

$=0.0469$

$\begin{array}{ll}\text { Pengaruh Total X1, X2 } & =0.517 \\ \text { Pengaruh Variabel lain } & =0.483\end{array}$

$\begin{array}{ll}\text { Pengaruh Total X1, X2 } & =0.517 \\ \text { Pengaruh Variabel lain } & =0.483\end{array}$

Berdasarkan hasil perhitungan di atas menunjukkan secara keseluruhan variabel nilainilai religi (X1) dan komitmen (X2) mempunyai pengaruh terhadap etos kerja pegawai (Y)

sebesar 0,517 atau $51,7 \%$ sedangkan sisanya dipengaruhi oleh variabel lain yaitu $48,3 \%$ yang tidak diteliti.

Adanya pengaruh positif nilai-nilai religi dan komitmen terhadap etos kerja pegawai dikarenakan nilai-nilai religi adalah serupa dengan konsep dan cita-cita yang menggerakan perilaku individu untuk menghasilkan etos kerja yang lebih baik.

\section{Pengaruh Nilai-Nilai Islam (X1) dan Komitmen (X2) Terhadap Kualitas Kerja (Z)}

Hasil pengolahan data dapat diketahui pengaruh secara parsial dan simultan nilai- nilai Islam dan komitmen terhadap kualitas Kerja dapat dilihat pada tabel 3.

Tabel 3. Pengaruh Secara Parsial dan Simultan Nilai- Nilai Islam dan Komitmen Terhadap Kualitas Kerja

\begin{tabular}{lrrrrrr}
\hline \multirow{2}{*}{ Model } & \multicolumn{2}{c}{$\begin{array}{l}\text { Unstandardized } \\
\text { Coefficients }\end{array}$} & $\begin{array}{c}\text { Standardized } \\
\text { Coefficients }\end{array}$ & \multirow{2}{*}{ T } & Sig \\
\cline { 2 - 4 } & $\mathrm{B}$ & $\begin{array}{c}\text { Std. } \\
\text { Error }\end{array}$ & \multicolumn{2}{c}{ Beta } & & \\
\hline (Constant) & 2.962 & 4.833 & & & .613 & .541 \\
\cline { 2 - 6 } Religi & .140 & .030 & .383 & 4.697 & .000 \\
\cline { 2 - 6 } Komitmen & .674 & .181 & .303 & 3.720 & .000 \\
\hline
\end{tabular}

Dependent Variable: Kualitas

Sumber: data diolah

Berdasarkan data pada tabel 3 tersebut dapat diketahui bahwa:

(1) Pengaruh secara parsial nilai-nilai religi terhadap kualitas kerja. Pengaruh secara parsial nilai-nilai religi terhadap kualitas kerja sumber daya manusia di lingkungan Pemerintah Kabupaten Tasikmalaya atau $\rho Z X 1$ sebesar 0,383 . Untuk pengujian hipotesis secara parsial pengaruh nilai-nilai religi (X1) terhadap kualitas kerja $(Z)$ dengan kriteria penolakan Ho jika $t$ hitung $>\mathrm{t}$ tabel.

Hasil penghitungan SPSS diperoleh $t$ hitung $=4,697$ sedangkan $\mathrm{t}$ tabel sebesar 1,66 dengan demikian $\mathrm{t}$ hitung $>\mathrm{t}$ tabel sehingga dapat dikatakan bahwa terdapat pengaruh positif nilai-nilai religi terhadap kualitas kerja pegawai.

Religiusitas diwujudkan dalam berbagai sisi kehidupan manusia. Aktivitas beragama bukan hanya terjadi ketika seseorang melakukan peribadatan (ritual), tapi juga ketika melakukan aktivitas lain yang di dorong oleh kekuatan supranatural. Bukan hanya yang berkaitan dengan aktivitas yang tampak dan dapat dilihat mata, tapi juga aktivitas yang tidak tampak dan terjadi dalam hati seseorang. Karena itu, keberagamaan seseorang akan meliputi berbagai macam sisi atau dimensi.

Dengan demikian, agama adalah sebuah sistem yang berdimensi banyak. Agama adalah sistem simbol, sistem keyakinan, sistem nilai dan sistem perilaku yang terlembagakan, yang semuanya itu berpusat pada persoalanpersoalan yang dihayati sebagai yang paling 
maknawi (ultimate meaning). Agama membentuk pribadi-pribadi yang kokoh dalam berperilaku, seperti, kejujuran, kedisiplinan, kesetiakawanan, keoptimisan, semangat, toleran. Karena pada dasarnya agama memang mengajarkan mengenai moral. Rasa keberagamaan seseorang (religiusitas) memiliki peran yang tidak kecil untuk memompa semangatnya dalam beraktifitas. Secara teoritis akan sangat berbeda kualitas kerja seseorang dalam bekerja antara orang yang tidak memiliki dasar agama yang kuat dan yang memiliki dasar agama yang telah tertempa melalui penga-laman dan pemahaman yang benar terhadap keyakinan agamanya.

(2) Pengaruh secara parsial komitmen terhadap kualitas kerja sumber daya manusia di lingkungan Pemerintah Kabupaten Tasikmalaya. Pengaruh secara parsial komitmen terhadap kualitas kerja sumber daya manusia di lingkungan Pemerintah Kabupaten Tasikmalaya atau $\rho Z X 2$ sebesar 0,303. Untuk pengujian hipotesis secara parsial pengaruh komitmen (X2) terhadap kualitas kerja (Z) dengan kriteria penolakan Ho jika $\mathrm{t}$ hitung $>\mathrm{t}$ tabel. Hasil penghitungan SPSS diperoleh $t$ hitung $=3,720$ sedangkan $t$ tabel sebesar 1,66 dengan demikian $\mathrm{t}$ hitung $>\mathrm{t}$ tabel sehingga dapat dikatakan bahwa terdapat pengaruh positif komitmen terhadap kualitas kerja.

Tingkat komitmen baik komitmen perusahaan terhadap karyawan, maupun antara karyawan terhadap perusahaan sangat diperlukan karena melalui komitmen-komitmen tersebut akan tercipta iklim kerja yang profesional. Komitmen organisasional merupakan "perspektif yang bersifat keperilakuan dimana komitmen diartikan sebagai perilaku yang konsisten dengan aktivitas (consistent lines of activity)" sehingga semakin tinggi komitmen karyawan tehadap organisasi dapat meningkatkan kinerja karyawan tersebut.

Semakin tinggi komitmen seseorang terhadap tugasnya maka akan semakin tinggi kinerja yang akan dihasilkan, yang menuju pada tingkat penilaian yang semakin tinggi. Komitmen organisasional berpengaruh signifikan terhadap kinerja. Semakin tinggi komitmen organisasional dari karyawan maka akan semakin meningkat kinerja individual karyawan. Komitmen dengan dimensi afektif, normative dan continuence terbukti secara signifikan memiliki pengaruh positif terhadap kualitas kerja.

Hasil penelitian Richard (1980) juga menunjukkan bahwa komitmen organisasional berpengaruh positif dan signifikan terhadap usaha kerja dan kinerja dengan koefisien jalur 0,446. Tingkat komitmen baik komitmen perusahaan terhadap karyawan, maupun antara karyawan terhadap perusahaan sangat diperlukan karena melalui komitmen-komitmen tersebut akan tercipta iklim kerja yang profesional. Komitmen organisasional merupakan "perspektif yang bersifat keperilakuan dimana komitmen diartikan sebagai perilaku yang konsisten dengan aktivitas (consistent lines of activity)" (Ivan Aris dan Imam Gozhali, 2006:193). Sehingga semakin tinggi komitmen karyawan tehadap organisasi dapat meningkatkan kinerja karyawan tersebut. Wright (2007) mendukung bahwa semakin tinggi komitmen seseorang terhadap tugasnya maka akan semakin tinggi kinerja yang akan dihasilkan, yang menuju pada tingkat penilaian yang semakin tinggi. Hal serupa juga di kemukakan oleh Rivai (2005:87) yang menyatakan bahwa komitmen organisasional berpengaruh signifikan terhadap kinerja. Semakin tinggi komitmen organisasional dari karyawan maka akan semakin meningkat kinerja individual karyawan. Hasil penelitian Setyaningdyah, et al.,(2013) menyatakan bahwa disiplin dan komitmen berpengaruh signifikan terhadap kinerja karyawan.

(3) Pengaruh secara simultan nilai-nilai religi dan komitmen terhadap kualitas kerja sumber daya manusia di lingkungan Pemerintah Kabupaten Tasikmalaya. Besarnya pengaruh secara simultan nilai-nilai religi (X1) dan 
komitmen (X2) terhadap kualitas kerja (Z) dapat dilihat dari indikator yang digunakan masing-masing variabel dengan menggunakan path analysis diperoleh hasil $\rho 2 z x 1 \times 2$ yang dapat dilihat pada tabel 4 .

Tabel 4. Besarnya pengaruh secara simultan nilai-nilai religi (X1) dan komitmen (X2) terhadap kualitas kerja (Z)

\begin{tabular}{ccccc}
\hline Model & $\mathrm{R}$ & $\begin{array}{c}\mathrm{R} \\
\text { Square }\end{array}$ & Adjusted R Square & $\begin{array}{c}\text { Std. Error } \\
\text { of the } \\
\text { Estimate }\end{array}$ \\
\hline 1 & $.579^{\mathrm{a}}$ & .335 & .324 & 3.47228 \\
\hline
\end{tabular}

Predictors: (Constant), Komitmen, Religi

Sumber: data diolah

Berdasarkan Tabel di atas terlihat nilai $\rho 2 z x 1 \times 2$ sebesar 0,335 atau $33,5 \%$ artinya jika nilai-nilai religi dan komitmen secara bersama-sama meningkat akan memberikan dampak positif, maka kualitas kerja pegawai juga akan meningkat. Untuk pengujian hipotesis secara simultan diperoleh nilai $\mathrm{F}$ hitung sebesar 30,434 > F-tabel 2,69 sehingga dapat disimpulkan bahwa terdapat pengaruh positif nilai-nilai religi dan komitmen terhadap kualitas kerja pegawai.

Secara lengkap pengaruh antara variabel nilai-nilai religi $(\mathrm{X} 1)$, dan komitmen $(\mathrm{X} 2)$ terhadap kualitas kerja (Z) dapat dilihat pada gambar 3 .

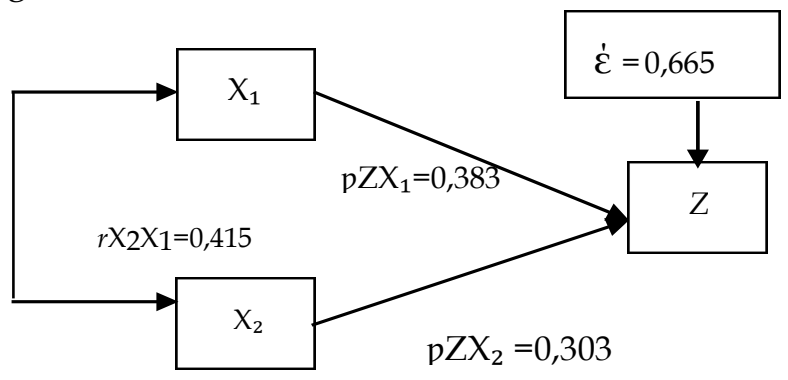

\section{Gambar 3. Nilai Koefisien Jalur Antara Variabel} $\mathrm{X} 1, \mathrm{X} 2$ dan $\mathrm{Z}$

Berdasarkan gambar 3 dapat dilihat pengaruh langsung dan tidak langsung antara variabel yaitu:

\section{Pengaruh (X1) terhadap Z:}

Pengaruh langsung

Pengaruh melalui (X2)

Pengaruh total (X1)

Analisis (X2) terhadap Z:

Pengaruh langsung

Pengaruh melalui (X1)

Pengaruh total (X2)

Pengaruh Total X1, X2,

Pengaruh Variabel lain

$$
\begin{aligned}
& =0,146689 \\
& =\underline{0,048160}+ \\
& =0,194849
\end{aligned}
$$

$=0,091809$

$=\underline{0,048160}+$

$=0,139969$

$=0,335$

$=0,665$
Berdasarkan hasil perhitungan di atas menunjukkan secara keseluruhan variabel nilainilai religi (X1), dan komitmen (X2) mempunyai pengaruh terhadap kualitas kerja pegawai $(Z)$ sebesar 0,335 atau 33,5 persen, sedangkan sisanya dipengaruhi oleh variabel lain yaitu 66,5 persen.

Adanya pengaruh positif nilai-nilai religi dan komitmen terhadap kualitas kerja menunjukkan bahwa penerapan nilai religi dan komitmen yang tinggi dari pegawai dapat menghasilkan kualitas kerja yang baik (Rohilah, Elah. 2010).

\section{Pengaruh Etos Kerja Terhadap Kualitas Kerja}

Hasil pengolahan data dapat diketahui pengaruh etos kerja terhadap kualitas sumber daya manusia di lingkungan Pemerintah Kabupaten Tasikmalaya yang dapat dilihat pada Tabel 5. 
Tabel 5. Pengaruh Etos Kerja Terhadap Kualitas Sumber Daya Manusia di Lingkungan Pemerintah Kabupaten Tasikmalaya

\begin{tabular}{|c|c|c|c|c|c|}
\hline \multirow{2}{*}{ Model } & \multicolumn{2}{|c|}{ Unstandardized Coefficients } & Standardized Coefficients & \multirow[b]{2}{*}{$\mathrm{t}$} & \multirow[b]{2}{*}{ Sig. } \\
\hline & B & Std. Error & Beta & & \\
\hline (Constant) & 2.835 & 4.762 & & .595 & .553 \\
\hline Religi & .085 & .039 & .233 & 2.195 & .030 \\
\hline Komitmen & .614 & .181 & .276 & 3.399 & .001 \\
\hline Etos & .303 & .141 & .226 & 2.149 & .034 \\
\hline
\end{tabular}

Dependent Variable: Kualitas

Sumber: data diolah

Berdasarkan tabel 5 terlihat bahwa etos kerja mempunyai pengaruh positif terhadap kualitas kerja. Hal ini ditunjukkan oleh $t$ hitung=2,149 sedangkan $\mathrm{t}$ - tabel sebesar 1,66 dengan demikian t-hitung>t-tabel sehingga hipotesis yang menyatakan bahwa terdapat pengaruh positif etos kerja terhadap kualitas kerja diterima.

Hasil ini mendukung hasil penelitian Irawan (2011) yang menunjukkan bahwa pada hipotesis etos kerja islami berpengaruh yang signifikan terhadap kualitas kerja karyawan, dimana hasil uji regresi asecara simultan diketahui bahwa nilai $\mathrm{F}$ hitung diperoleh sebesar 47,251 lebih besar dari nilai F-tabel 2,30. Islam menuntut dan mengarahkan kaum muslimin untuk melakukan tindakan sesuai dengan apa yang dibolehkan dan dilarang oleh Allah SWT. Demikian pula dalam melaksanakan aktivitas ekonomi, nilai-nilai Islam senantiasa menjadi landasan utamanya.

\section{Pengaruh Nilai-Nilai Religi, Komitmen dan Etos Kerja terhadap Kualitas Kerja}

Pengaruh nilai-nilai religi (X1) dan komitmen (X2) terhadap etos kerja (Y) dan dampaknya terhadap kualitas Kerja (Z) sumber daya manusia di lingkungan Pemerintah Kabupaten Tasikmalaya dapat dilihat pada tabel 6.

Tabel 6. Pengaruh Nilai-Nilai Religi, Komitmen dan Etos Kerja terhadap Kualitas Kerja

\begin{tabular}{|c|c|c|c|c|c|}
\hline \multirow[t]{2}{*}{ Model } & \multicolumn{2}{|c|}{ Unstandardized Coefficients } & \multicolumn{2}{|c|}{$\begin{array}{c}\text { Standardized } \\
\text { Coefficients }\end{array}$} & \multirow[t]{2}{*}{ Sign } \\
\hline & B & Std. Error & Beta & $\mathrm{t}$ & \\
\hline (Constant) & 2.835 & 4.762 & & .595 & \\
\hline Religi & .085 & .039 & .233 & 2.195 & .030 \\
\hline Komitmen & .614 & .181 & .276 & 3.399 & .001 \\
\hline Etos & .303 & .141 & .226 & 2.149 & .034 \\
\hline
\end{tabular}

Dependent Variable: Kualitas

Sumber: data diolah

Berdasarkan data pada tabel 6 terlihat bahwa besar pengaruh nilai-nilai religi (X1) dan komitmen (X2) terhadap etos kerja (Y) dan dampaknya terhadap kualitas kerja (Z) sumber daya manusia di lingkungan Pemerintah Kabupaten Tasikmalaya sebesar 35,9\% yang dapat digambarkan pada gambar 4 .

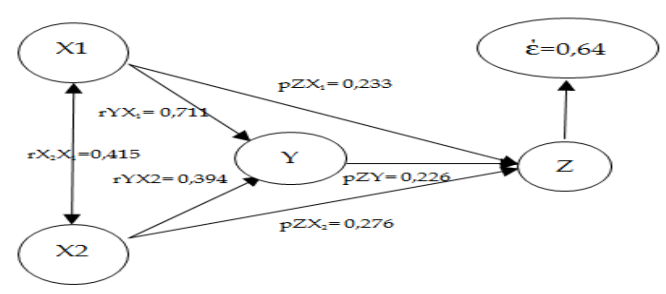

\section{Gambar 4. Nilai Koefisien Jalur Antara Variabel X1, X2, Y dan Z}

Berdasarkan hasil perhitungan di atas 
menunjukkan secara keseluruhan variabel nilainilai religi (X1) dan komitmen mempunyai pengaruh positif terhadap etos kerja (Y) dan mempunyai dampak positif terhadap kualitas kerja sebesar 35,9\% sedangkan sisanya dipengaruhi oleh variabel lain yaitu $64,1 \%$. Untuk pengujian hipotesis secara simultan diperoleh nilai F-hitung sebesar 22,435 > F-tabel 2,69 sehingga dapat disimpulkan bahwa terdapat pengaruh positif nilai-nilai religi dan komitmen terhadap etos kerja dan berdampak positif terhadap kualitas kerja sumber daya manusia di lingkungan pemerintah Kabupaten Tasikmalaya. Adapun pengaruh masing-masing variable bebas terhadap variabel terikat baik secara langsung maupun tidak langsung penulis sajikan dalam tabel 7.

Tabel 7. Pengaruh Masing-Masing Variabel

Bebas terhadap Variable Terikat Baik Secara Langsung maupun Tidak Langsung

\begin{tabular}{|c|c|}
\hline Keterangan & Nilai \\
\hline \multicolumn{2}{|l|}{ Pengaruh X1 terhadap Y } \\
\hline Pengaruh langsung X1Terhadap & 0.4382 \\
\hline Pengaruh tidak langsung melalui $\mathrm{X}_{2}$ & 0.0327 \\
\hline Pengaruh Total $\mathrm{X}_{1}$ terhadap $\mathrm{Y}$ & 0.4709 \\
\hline \multicolumn{2}{|l|}{ Pengaruh $\mathrm{X} 2$ terhadap $\mathrm{Y}$} \\
\hline Pengaruh langsung $\mathrm{X}$ 2Terhadap $\mathrm{Y}$ & 0.0142 \\
\hline Pengaruh tidak langsung $\mathrm{X}_{2}$ melalui $\left(\mathrm{X}_{1}\right)$ & 0.0327 \\
\hline Pengaruh total $\left(\mathrm{X}_{2}\right)$ terhadap $\mathrm{Y}$ & 0.0469 \\
\hline Total Pengaruh X1, X2 terhadap $\mathrm{Y}$ & 0.5178 \\
\hline \multicolumn{2}{|l|}{ Pengaruh X1 terhadap Z } \\
\hline Pengaruh langsung X1Terhadap Z & 0.0543 \\
\hline Pengaruh tidak langsung $\mathrm{X}_{1}$ melalui $\mathrm{X}_{2}$ & 0.0267 \\
\hline Pengaruh tidak langsung $\mathrm{X} 1$ melalui $\mathrm{Y}=$ & 0.0749 \\
\hline Pengaruh Total $\mathrm{X}_{1}$ terhadap $\mathrm{Z}$ & 0.1559 \\
\hline \multicolumn{2}{|l|}{ Pengaruh $\mathrm{X} 2$ terhadap $\mathrm{Z}$} \\
\hline Pengaruh langsung X2Terhadap Z & 0.0762 \\
\hline Pengaruh tidak langsung $\mathrm{X}_{2}$ melalui $\left(\mathrm{X}_{1}\right)$ & 0.0267 \\
\hline Pengaruh tidak langsung $\mathrm{X}_{2}$ melalui $\mathrm{Y}=$ & 0.0887 \\
\hline Pengaruh Total $\mathrm{X}_{2}$ terhadap Z & 0.1916 \\
\hline Total Pengaruh X1, X2 terhadap Z & 0.2446 \\
\hline Pengaruh Y Terhadap Z & 0.051 \\
\hline Totla Pengaruh $\mathrm{X} 1, \mathrm{X} 2$, dan $\mathrm{Y}$ terhadap Z & 0.359 \\
\hline
\end{tabular}

Berdasarkan hasil perhitungan di atas dapat dijelaskan bahwa besarnya pengaruh langsung penerapan nilai-nilai religi terhadap kualitas kerja adalah sebesar 5,43\% dan pengaruh tidak langsungnya melalui komitmen sebesar 2,67\% dan melalui etos kerja sebesar $7,49 \%$. Sedangkan pengaruh langsung komitmen terhadap kualitas kerja adalah sebesar 7,62\% dan pengaruh tidak langsungnya melalui nilai-nilai religi sebesar $2,67 \%$ dan melalui etos kerja sebesar 8,86\%. Pengaruh langsung etos kerja terhadap kualitas kerja sumber daya manusia sebesar $5,10 \%$.

Hasil penelitian tersebut memberi gambaran bahwa variabel nilai-nilai religi mempunyai pengaruh terhadap etos kerja dan kualitas kerja sumber daya manusia pegawai, variabel religi dan variabel komitmen yang diterapkan oleh Pegawai Negeri Sipil di lingkungan Pemerintah Kabupaten Tasikmalaya dapat meningkatkan etos kerja yang berdampak terhadap meningkatnya kualitas kerja sumber daya manusia. Pada penelitian ini besarnya pengaruh penerapan nilai-nilai religi, komitmen dan etos kerja terhadap kualitas kerja sumber daya manusia sebesar 35,9 \% berarti ada variabel lain yang berpengaruh besar terhadap kualitas kerja sebesar 64,1 \%. Hal ini dapat disebabkan karena implementasi dari nilai-nilai religi masih ada item-item yang belum dilaksanakan, demikian juga dengan komitmen pegawai yang belum dilakukan secara sungguhsungguh.

\section{SIMPULAN}

Berdasarkan analisis hasil penelitian tentang Pengaruh Penerapan Nilai-Nilai Islam dan Komitmen Terhadap Etos Kerja dan Dampaknya Kepada Kualitas Kerja sumber daya manusia di lingkungan Pemerintah Kabupaten Tasikmalaya, dapat ditarik kesimpulan sebagai berikut:

1. Terdapat pengaruh positif baik secara parsial maupun secara simultan nilai-nilai Islam dan komitmen terhadap Etos Kerja sumber daya manusia di lingkungan Pemerintah Kabupaten Tasikmalaya.

2. Terdapat pengaruh positif baik secara parsial maupun secara simultan nilai-nilai Islam dan 
komitmen terhadap kualitas kerja sumber daya manusia di lingkungan Pemerintah Kabupaten Tasikmalaya.

3. Terdapat pengaruh positif etos kerja terhadap kualitas kerja sumber daya manusia di lingkungan Pemerintah Kabupaten Tasikmalaya.

4. Terdapat pengaruh positif baik secara parsial maupun secara simultan nilai-nilai Islam dan komitmen terhadap etos kerja dan berdampak positif terhadap kualitas kerja sumber daya manusia di lingkungan Pemerintah Kabupaten Tasikmalaya.

\section{DAFTAR PUSTAKA}

Ancok dan Suroso, 2008. Psikologi Islam, Pustaka Pelajar: Yogyakarta.

Aries, Ivan dan Imam Ghozali. 2006. "Akuntansi Keperilakuan". Semarang: Universitas Diponegoro.

Imam, Gozhali, 2001, Aplikasi Analisis Multivariate dengan Program SPSS, Edisi 2, Badan Penerbit Universitas Diponegoro, Semarang

Morris, James H., Steers, Richard M. (1980). "Structural Influences on Organizational Commitment." Journal of Vocational Behaviour, 17 (1): 50-57

Rivai, Harif A 2001, 'Pengaruh Kepuasan Gaji, Kepuasan Kerja, dan Komitmen Organisasional terhadap Intensi Keluar: Pengujian Empiris Model Turnover', Jurnal Bisnis dan Akuntansi. Vol. 3, No,1, April 2001 hal 335-352.

Rivai, Harif A 2005, 'Pengaruh Kompensasi, komitmen Organisasional, dan Kompetensi terhadap Kinerja Individual', Kajian Bisnis, Vol. 3, September-Desember 2005, 272-286

Rohilah, Elah. 2010. Nilai-Nilai Islam dalam Sumber Daya Manusia. Seminar Manajemen Sumber Daya Manusia. Bandung

Santoso, 2006. Etos Kerja Pengusaha Muslim Perkotaan di Kota Ponorogo. Jurnal
Penelitian Humaniora, Edisi Khusus, Juni 2006:115-125.Ponorogo:Universitas Muhammadiyah Ponorogo.

Setyaningdyah, E., Kertahadi, U.N., dan Thoyib, A (2013), "The Effects of Human Resource Competence, Organisational Commitment and Transactional Leadership on Work Discipline, Job Satisfaction and Employees performance", Interdisciplinary Journal Of Contemporary Research In Business, 5 (4), page 9.

Sinamo, J. 2008. Ethos 21: Etos Kerja Profesional di Era Digital Global. Jakarta: Penerbit Institut Darma Mahardika.

Wright, P. M. \& Kehoe, R. R. (2007). Human resource practices and organizational commitment: A deeper examination (CAHRS Working Paper \#07-15). Ithaca, NY: Cornell University, School of Industrial and Labor Relations, Center for Advanced Human Resource Studies. http:// digitalcommons.ilr.cornell.edu/cahrswp/ 